\title{
МОЗАЇЧНІ ТВОРИ В АРХІТЕКТУРІ ВІННИЧЧИНИ ДРУГОї ПОЛОВИНИ ХХ СТ.
}

\author{
Петров О. О., Петрова I. B.
}

\section{ВСТУП}

Ухвалення Закону «Про засудження комуністичного та націоналсоціалістичного (нацистського) тоталітарних режимів в Україні та заборону пропаганди їхньої символіки» актуалізувало питання каталогізації та збереження творів монументального мистецтва (мозаїк, вітражів, сграфіто). Хоч у ст. 4 документа зазначено, що «заборона не поширюється на випадки використання символіки комуністичного тоталітарного режиму... у творах мистецтва, створених до набрання чинності цим Законом» ${ }^{1}$, місцева влада та приватні власники будівель намагаються позбутись у публічному просторі «символіки» радянського періоду ${ }^{2}$. На сьогодні є декілька реалізованих всеукраїнських проєктів, спрямованих на формування відкритого архіву пам'яток монументального мистецтва та їхнього збереження задля подальшої музеєфікації та експонування («6 МОЗАЇК», «Soviet Mosaics in Ukraine», «Монументальні пам'ятки пізнього модернізму Житомира та Житомирської області») $)^{3}$. На жаль, під загрозою знищення зараз перебувають не тільки мозаїчні панно, але й інші монументальні твори: художні вітражі в громадських та приватних об'єктах, монументальні розписи (сграфіто), скульптурні рельєфні композиції (декоративні панно) 3 дерева, кераміки, латуні. Для Вінницької області проєкт збереження зразків монументального мистецтва особливо

1 Закон України «Про засудження комуністичного та націонал-соціалістичного (нацистського) тоталітарних режимів в Україні та заборону пропаганди їхньої символіки» від 9 квітня 2015 p. URL : http://zakon4.rada.gov.ua/ laws/show/317-19 від 09.04.2015.

${ }^{2}$ Моляр Є. Радянська монументалістика: предмет декомунізації чи урбанайдентика. URL : https://mistosite.org.ua/ru/articles/radianska-monumentalistykapredmet-dekomunizatsii-chy-urban-aidentyka.

${ }^{3}$ Монументальні пам'ятки пізнього модернізму Житомира та Житомирської області. URL : http://monumentalart.in.ua. 
актуальний, оскільки зараз відбувається тотальне знищення мозаїчних творів радянського періоду. Тому проведення повної каталогізації та фіксації всіх наявних мозаїк, установлення їхніх атрибутивних ознак на сьогодні $є$ першочерговою проблемою.

Мета дослідження - визначити закономірності розвитку монументального мистецтва Вінниччини та розкрити художні особливості мозаїчних творів Г. Солдатова, В. Байбекова, С. Кочергана та ін. До проблеми дослідження та збереження мозаїк радянського минулого в Україні зверталися вчені та митці Л. Жоголь ${ }^{4}$, Г. Скляренко ${ }^{5}$, Н. Велігоцька ${ }^{6}$, Л. Огнєва ${ }^{7}$, Л. Гринюк ${ }^{8}$, Є. Моляр ${ }^{9}$, Б. Лобановський ${ }^{10}$, Є. Нікіфоров ${ }^{11}$, А. Дробот ${ }^{12}$, Н. Піддубна ${ }^{13}$ та ін.

Основними джерелами для упорядкування роботи стали результати досліджень архітектурних об'єктів Вінниці та Вінницької області, фотоматеріали, зібрані I. Петровою та

${ }^{4}$ Жоголь Л.Е. Декоративное искусство в интерьерах общественных зданий. Киев : «Будивельнык», 1978. 104 с.

5 Скляренко Г. Мистецтво і місто. Роль монументально-декоративного мистецтва у формуванні естетичного середовища соціалістичного міста. Київ : Товариство «Знання» Української РСР, серія 6 «Література і мистецтво», 1987. 48 с.

6 Велігоцька Н.І. Монументально-декоративное искусство в архитектуре Украины. Київ : Будівельник, 1988. $101 \mathrm{c}$.

7 Огнєва Л. Перлини монументального мистецтва на Донеччині. ІваноФранківськ : Лілея, 2008. 52 с.

${ }^{8}$ Монументальне мистецтво у творчості художників Вінниччини / Вінниц. обл. орг. Нац. спілки художників України; упоряд.: Л. Гринюк. Вінниця : Консоль, 2009. $119 \mathrm{c}$.

9 Моляр Є. «В Маріуполі має бути створений музей монументальнодекоративного мистецтва». URL : http://www.korydor.in.ua/ua/opinions/yevgeniyamolyar-v-mariupoli-maye-buty-stvorenij-muzej-monumentalno-dekorativnogomistetstva.html.

${ }^{10}$ Лобановський Б. Мозаїки і фрески. Київ : Мистецтво, 1966. 134 с.

${ }^{11}$ NikiforovY. Decommunized: Ukrainian Soviet Mosaics. Edited by Olga Balashova and LizavetaGerman.

Kyiv : OsnovyPublishing, 2017. 250 p.

12 Дробот А.О. Проблема національного стилю у творчості Г. Синиці (на прикладах мозаїчних панно другої половини ХХ ст.). Вісник Харківської державної академії дизайну і мистецтв: збірка наукових пращь. 2008. Вип. 13. С. 24-34.

${ }^{13}$ Піддубна Н. Г. Композиційні принципи застосування мозаїчних творів в архітектурі Львова кінця XIX - початку XXI століття : дисертація на здобуття наукового ступеня кандидата архітектури : 18.00 .01 - теорія архітектури, реставрація пам'яток архітектури. Міністерство освіти i науки України, Національний університет «Львівська політехніка». Львів, 2018. 342 с. 
О. Петровим протягом 2017-2019 рр., а також мистецькі твори, що перебувають на обліку в Державному архіві Вінницької області у фондах Вінницької організації спілки художників України (19761983 рр.), Вінницьких художньо-виробничих майстерень художнього фонду СРСР (за 1950-1987 pp.).

\section{1. Особливості мозаїчних композицій радянського періоду} в громадських та промислових спорудах Вінниччини

Монументальні мозаїки, вітражі, сграфіто в громадських і житлових спорудах Вінниччини почали масово з'являтися після 1955 р., зі зміною принципів будівництва (державна постанова від 1955 р. «Про усунення надлишків у проєктуванні та будівництві» та низка інших документів, як-от: накази «Про заходи щодо подальшої індустріалізації, поліпшення якості та зниження вартості будівництва» 1956 р. і «Про розвиток житлового будівництва в СРСР» 1957 р). Новим етапом у розвитку монументального мистецтва в УРСР стало прийняття ЦК КП України постанови «Про заходи до поліпшення монументального та архітектурнохудожнього оформлення міст і сіл Української РСР» (від 2 квітня 1969 р., №222). У постанові зазначалося, що «до цього часу 3'являються пам'ятники, монументи, пам'ятні знаки, мозаїчні панно, виконані на низькому ідейно-художньому рівні, позначені елементами формалізму й модернізму, в яких образи наших людей у збідненому, огрубленому вигляді». Тому Художній фонд УРСР запропонував проєкти архітектурно-художнього оформлення громадських споруд після ухвалення художньою радою підприємства обов'язково подавати на розгляд Республіканської ради ХФ УРСР, а потім - на художню раду Держбуду (особливо останне зауваження поширювалося на проєкти архітектурнохудожніх рішень фасадів та інтер'єрів громадських споруд і житлових будинків, вартість робіт за якими перевищувала 5 тис. карб.). На думку керівництва ЦК КП України, це повинно було сприяти підвищенню ідеологічного та художнього рівнів окремих творів мистецтва.

Більшість замовлень на виробництво мозаїчних композицій угромадських спорудах місцеві художники отримували через Вінницькі художньо-виробничі майстерні художнього фонду СРСР (зараз - Вінницький художньо-виробничий комбінат), створені в 1963 р. Майстерні входили до складу Художнього фонду Української РСР разом із Київським живописно-скульптурним 
комбінатом, Київським, Кримським, Донецьким, Ворошиловградським, Харківським, Львівським художньо-виробничими комбінатами; Львівською кераміко-скульптурною фабрикою; Харківськими, Закарпатськими, Севастопольськими, Кіровоградськими, Черкаськими, Запорізькими, Сумськими художньовиробничими майстернями тощо. Пізніше, у 1976 р., було засновано Вінницьку обласну організацію художників України. Першим іiі обранцем стає Валерій Вакалюк ${ }^{14}$. У 1977 р. до Вінниці прибули випускники художніх вишів СРСР, що дозволило зміцнити фахові секції- живопису, скульптури й графіки - й утворити новідекоративно-ужиткового мистецтва, монументалістики. Серед молоді були митці, які активно залучалися до створення монументальних композицій: Г. Солдатов, В. Байбеков, І. Ященко, Л. Гринюк, В. Ямковенко, В. Купчишин, С. Кочерган, Ю. Кобиляцький, С. Гладков, М. Соболь, П. Гонтар, О. Янголь, I. Сінєпольський, С.Гладков, В. Вакалюк, В. Рубіш та ін.

Над мозаїчними композиціями активно працював Сергій Вікторович Кочерган (член Національної спілки художників України з 1977 р.). У 1972 р. він закінчив факультет графіки Київського державного художнього інституту. Під його керівництвом було реалізовано масштабний проєкт оформлення інтер'єрів та екстер'єрів споруд Вінницького політехнічного інституту (зараз Вінницький національний технічний університет І.П., О.П.). Серед найбільш відомих робіт С. Кочергана для Вінницького національного технічного університету $є$ «Наука і космос» (рис. 1) (виконавці С. Кочерган, Д. Олійник, А. Яблонський; 1990 р., 1800х700) та «Будівельники» (рис.2) (автор С. Кочерган; виконавці Д. Олійник, Г. Мельник, А. Яблонський; 1991 p., 1800x700).

В оформленні фасадів будівель Вінницького національного технічного університету брав участь В. Ямковенко. Йому належить мозаїка «Наука» (рис. 3) (1986 р., 1200х400). Протягом 1985-1986 pp. В. Ямковенко працював над ескізом іншої мозаїки для цього закладу «ЕОМ та навчальний процес» (рис. 5). У 1974 р. О. Янголь створює композицію «Щедрість осені» (рис. 4). Інтер'єр

14 Вінницька обласна організація Національної спілки художників України. URL : https://nuau1938.wixsite.com/nuau/vinnuau. 
університету прикрашає монументальний розпис А. Ступнікова «Енергетика» $(1980 \text { р. })^{15}$ та «Студентські роки» $(1982 \text { р. })^{16}$.

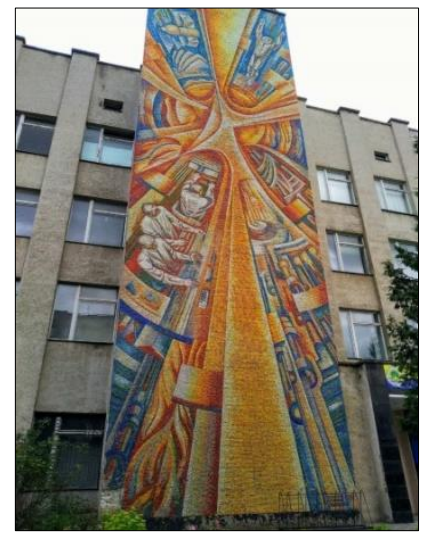

Рис. 1. Кочерган С. «Наука і космос» (виконавці Кочерган С., Олійник Д., Яблонський А.; 1990 р., 1800х700, Вінницький національний технічний університет, Вінниця)

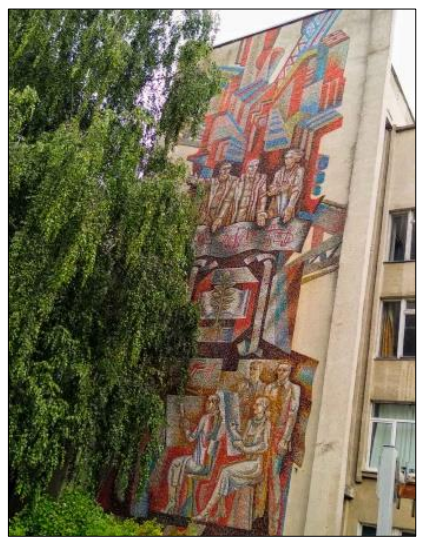

Рис. 2. Кочерган С. Будівельники (виконавці Олійник Д., Мельник Г., Яблонський А.; 1991 р., $1800 \times 700$, Вінницький національний технічний університет, м. Вінниця)

У комплексі мозаїчних панно «Будівельники», «Наука і космос» спостерігається бажання заглибитись у специфіку різних професій та опоетизувати працю як спосіб перетворення світу. Праця, наука, освіта, техніка подаються в нерозривній єдності, характерній для доби науково-технічної революції. У сюжетних групах («Наука») ця тема набуває подальшого розвитку: молоді інженери, що проєктують архітектурні споруди; студенти, що засвоюють знання. Отже, це була своєрідна спроба відтворити складність і розмаїтість сучасності в межах одного комплексу.

15 Выписки из протоколов заседаний Республиканского Художественного Совета (23 января - 24 декабря 1980 г.) // Державний архів Вінницької області. Ф. 5698. Оп.1. Спр. 224. Арк.3.

16 Выписки из протокола заседаний Республиканского Художественного совета (20 января - 15 декабря 1982 г.) // Державний архів Вінницької області. Ф. 5698. Оп.1. Спр. 248. Арк. 18. 


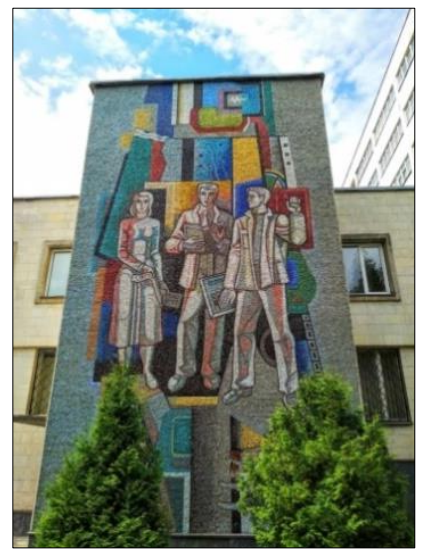

Рис. 3. Ямковенко В. «Наука» (1986 р., 1200x400, Вінницький національний технічний університет, м. Вінниця)

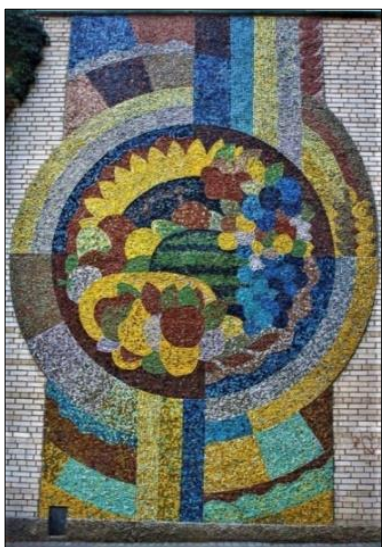

Рис. 4. Янголь О. «Щедрість осені» $(1200 \times 500,1974$ р. Вінницький національний технічний університет, м. Вінниця)

Роботи цікаві увагою до образу сучасника, ліричним трактуванням серйозних тем, прагненням через конкретні сюжети розв'язати глибокі філософські проблеми. У мозаїці «ЕОМ та навчальний процес» (рис. 5) В. Ямковенко використав для сучасної монументалістики символіко-алегоричне вираження: це техніка, яка панує в житті людини, і знання, що розвивають промисловий комплекс i суспільство, збагачують уявлення людини про навколишній світ, сприяють осягненню ролі штучного інтелекту.

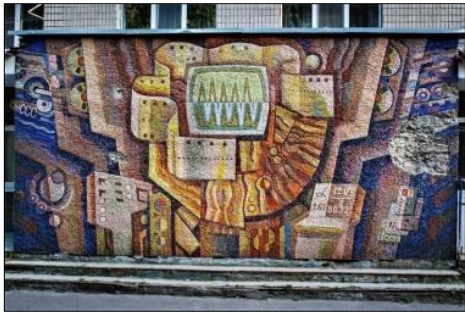

Рис. 5. Ямковенко В. «ЕОМ та навчальний процес» $(300 \times 1200$, 1985 р., Вінницький національний технічний університет, м. Вінниця)

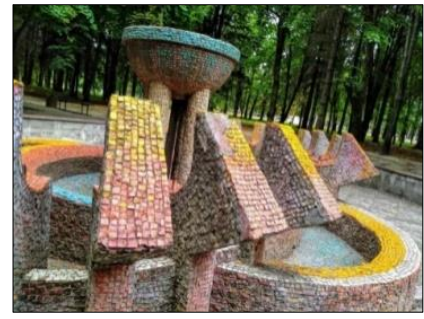

Рис. 6. Кочерган С., Олійник Д., Яблонський А. Фонтан. (1990 р., Вінницький національний технічний університет, м. Вінниця) 
Тривалий час на теренах Вінниччини працював Вільдан Умарович Байбеков, член Національної спілки художників України з 1977 р. Він розробляв жанри станкового та монументального живопису. В. Байбеков народився 7 травня 1948 р. в Самарканді (Узбекистан). 31956 до 1963 р. займався у студії образотворчого мистецтва Самаркандського палацу піонерів під керівництвом С. Ракової. Закінчив Республіканське художнє училище імені П. Бенькова в Ташкенті (1968, живописно-педагогічне відділення; педагоги П. Мартаков, Н. Шин). Дипломний проєкт - серія із трьох робіт «Діти» (керівник - Н. Шин). У 1968 р. вступив до Харківського державного художньо-промислового інституту на спеціальність «Монументально-декоративне мистецтво» (факультет «Інтер'єр та обладнання», 1973; педагоги Б. Косарев, Є. Сгоров, заслужений діяч А. Хмельницький. Дипломна робота - «Розпис для Самаркандського музею історії та мистецтва» (під керівництвом А. Хмельницького й архітектора В. Константинова) ${ }^{17}$.

Також В. Байбеков долучився до оздоблення Палацу урочистих подій у Вінниці (це замовлення було отримано Вінницькими художньо-виробничими майстернями 23 березня 1979 р.). В. Байбеков працював над створенням панно протягом року (1980 р., 1200x300, Палац урочистих подій, Вінниця) (рис. 7). Колектив вінницьких майстрів, яким було доручено монументальнодекоративне оформлення палацу, створив оригінальний комплекс, що оспівує всепереможне торжество щасливого кохання. В ансамблі вдало поєднанні два, здавалось би, протилежні начала - тонка лірика й епічність монументального мислення (автори В. Байбеков, А. Бурдейний, В. Рубіш, В. Вакалюк, Ю. Кизимов, Є. Кизимова, I. Ященко, 1980 р.). Монументально-декоративне оформлення будівлі й емоційні акценти в системі вулиць доповнюють простір образним ладом, кольором, пластикою. Так функції інтер'єру й екстер'єру комплексу набувають художнього осмислення в системі міста, району, вулиці. Між інтер'єром та екстер'єром утворюються складні змістовні й просторові зв'язки, середовище набуває багатомірності, пластично-колірної насиченості ${ }^{18}$.

17 Особова справа Вільдана Байбекова // Центральний державний архівмузей літератури і мистецтв України. Ф. 581. Оп. 2. Спр. 706. Арк. 3.

18 Монументальне мистецтво у творчості художників Вінниччини / Вінниц. обл. орг. Нац. спілки художників України; упоряд.: Л. Гринюк. Вінниця : Консоль, 2009. C. 30 . 

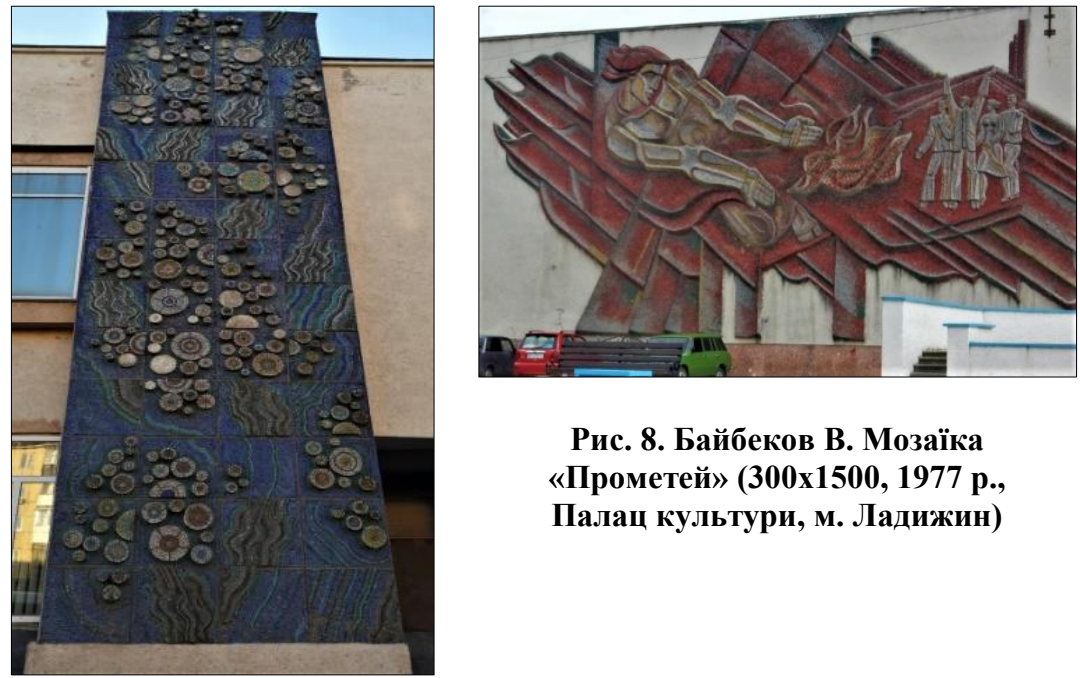

Рис. 8. Байбеков В. Мозаїка «Прометей» (300x1500, 1977 р., Палац культури, м. Ладижин)

Рис. 7. Байбеков В.

Декоративне панно

(1200x300, 1980 р., Палац

урочистих подій,

м. Вінниця)

Одними 3 перших монументальних робіт В. Байбекова були мозаїчне панно «Прометей» та декоративний розпис «Людина і природа» (900x330, 1976 р., левкас, темпера) для Палацу культури (колишній Громадсько-культурний центр - І.П., О.П.) Ладижинської ТЕС (1977 р.) (рис. 8). Палац побудований за типовим проєктом: він має глуху стіну, яку дуже часто відводять під монументальний розпис. В Україні образ Прометея сприймався завжди, і свідченням цього є вірші Тараса Шевченка. Для побудови композиції автор вибрав діагональне рішення. Мозаїка пронизана пафосом героїзму та жертовності, для зосередження глядацької уваги на образі Прометея автор використовує насичені кольори: червоний, жовтий, чорний. Ритмічна динаміка світлових плям додає площині відчуття свята, радісного настрою. Зображення умовне, але його вільний ритм, відкритий колір, виразність декоративної побудови наповнюють архітектурний простір вулиці людськими почуттями, життєвою активністю. 

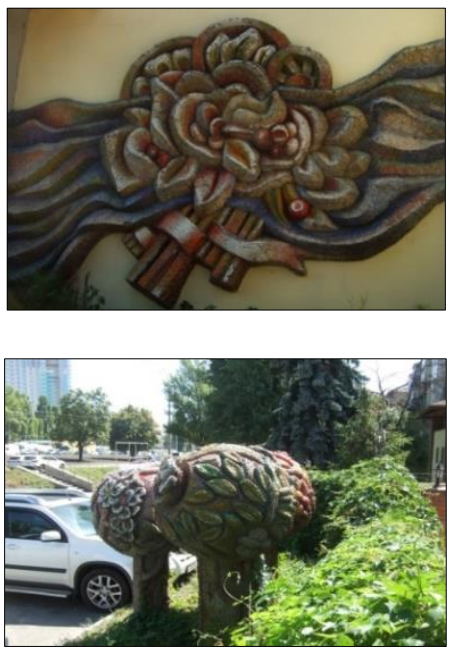

Рис. 9. Байбеков В. Композиція «Ласкаво просимо»

та монументально-декоративне оформлення зони відпочинку, кафе «Вінничанка», 1980-1982 pp.

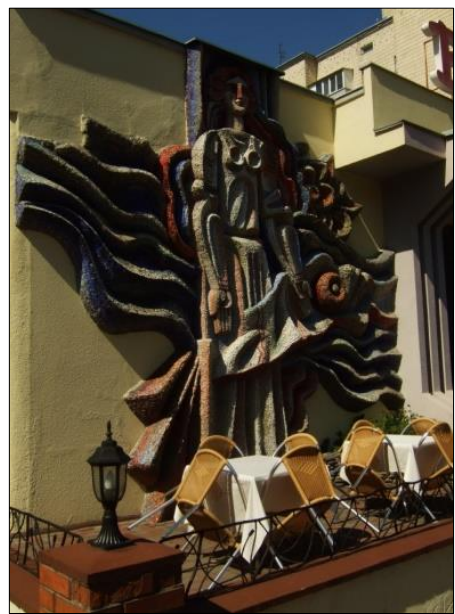

Рис. 10. Байбеков В. Композиція «Ласкаво просимо» $(800 \times 800)$ та монументальнодекоративне оформлення зони відпочинку, кафе «Вінничанка», 1980 -1982 рр.

Протягом 1980-1982 рр. В. Байбеков брав активну участь у масштабному проєкті - монументально-декоративному оформленні на замовлення Тресту їдалень Московського району Києва кафе «Вінничанка» (зараз ресторан «Будьмо!» - І.П., О.П.). Йому належить авторство мозаїки на фасаді споруди (композиція «Ласкаво просимо») та оформлення зони відпочинку ${ }^{19}$ (рис. 9-10). До складу авторського колективу входили О. Попенко (художній проєкт із оформлення кафе), Ю. Кизимов (гобелен-диптих «Південний Буг»), В. Вакалюк, В. Рубіш (монументальне керамічне панно «Вінницькі мотиви»), І. Синєпольський (оригінальна картина «Міський пейзаж Вінниці»). Для цього закладу В. Байбеков розробив також панно «Яблуко» (автор Д. Кудлаєнко). Крім того, в межах проєкту були розроблені ескізи панно «Подільські вікна», «Журавлина сім'я», «Тепло літа», «Вінок Бугу» (автори В. Вакалюк,

19 Книга протоколов заседания комиссии по распределению заказов (17 февраля 1979 г. - 11 марта 1982 г.) // Державний архів Вінницької області. Ф. 5698. Оп.1. Спр. 215. Арк. 48. 
В. Рубіш) ${ }^{20}$. Під час оформлення інтер'єру використовувалася стилізація під старовину. В інтер'єрі застосовано кілька видів декоративного мистецтва (розпис по левкасу, художній текстиль, кераміка, скло), але всі вони ніби доповнюють одне одного. Стіни кафе прикрашають гобелени на тему Південного Бугу, торець панно «Ласкаво просимо». Панно сприймається самостійно та завдяки високій майстерності художника слугує акцентом в екстер'єрі. В основі твору лежить образ дівчини-вінничанки у традиційному українському вбранні. Витонченість малюнка, орнаментальність композиції, фольклорність зображуваних метафор формують картину, у якій немає вираженого сюжету, але сам мотив дівочої краси та гостинності, м'які, округлі ритми, прозорість кольору надають їй глибокого ліризму.

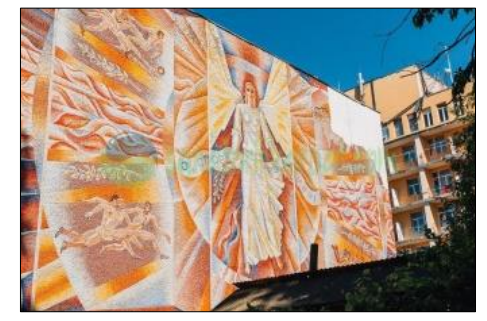

Рис. 11. Байбеков В., Каспрук

В. Мозаїка «Спорт», 200х1000, 1982 р., санаторій «Поділля», м. Хмільник, Вінницька область

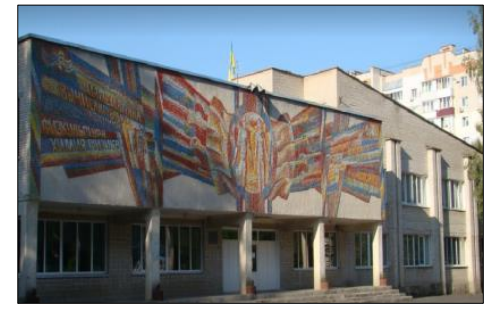

Рис. 12. Байбеков В., Одринський В., Гончар В., Сущук

Б. Мозаӥка «Знання», 500x1600, 1982 р., школа № 18, м. Вінниця

Серед інших відомих монументальних робіт В. Байбекова слід назвати мозаїчне панно «Сонце, повітря та вода» для санаторію Міністерства оборони, Хмільника Вінницької області (1975 p., 800x800); декоративне панно «Енергетика» для Палацу культури Ладижинської ТЕС (у співавторстві з А. Бурдейним, 1976 р., 190x145, шамот, емалі, підглазурний розпис); декоративний розпис «Ікар» для Вінницького військово-медичного клінічного центру Центрального регіону (1976 р., 320х700); мозаїку «Знання» (автор В. Байбеков, виконавці В. Одринський, В. Гончар, Б. Сущук,

${ }^{20}$ Выписки из протокола заседаний Республиканского Художественного совета (28 января - 9 декабря 1981г.) // Державний архів Вінницької області. Ф. 5698. Оп.1. Спр. 238. Арк. 15. 
1982 р., 1600х500); школа № 18 Вінниці; «Спорт» для санаторію «Поділля» (співавтор В. Каспрук, 1982 р., 800х760) (рис. 10-11); «Піонерія» для Палацу піонерів та учнів Жмеринки Вінницької області (співавтор Ю. Кобиляцький, 1986 р.) (рис. 15) ${ }^{21}$. Також у листопаді 1978 р. В. Байбеков розробив ескіз монументального панно «Медицина» для санаторію ВПС ${ }^{22}$. 15 серпня 1984 р. запропонував на обговорення Республіканської художньої ради ескіз «Розвиток» на замовлення Державного проєктного інституту (проєкт було реалізовано) ${ }^{23}$. Опрацьовуючи спортивну проблематику, В. Каспрук, В. Байбеков уславлюють красу людського тіла, енергію міцних м'язів. Спортсмени показані в русі: вони бігають, стрибають, ганяють м'яча, передають естафетну паличку. Мозаїка пройнята гуманістичним пафосом, що спорт $\epsilon$ запорукою миру. Ця сама думка висловлена в олімпійському гімні: «О спорт! Ти - мир!».

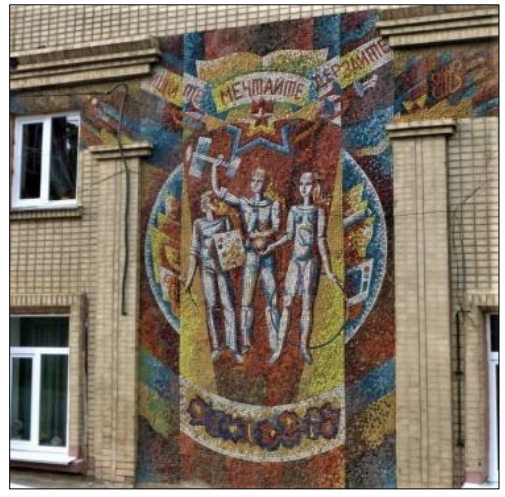

Рис. 13. Кобиляцький Ю., Байбеков

В. «Піонерія». (800x400, 1986 р., Палац піонерів та учнів м. Жмеринка, Вінницька область.

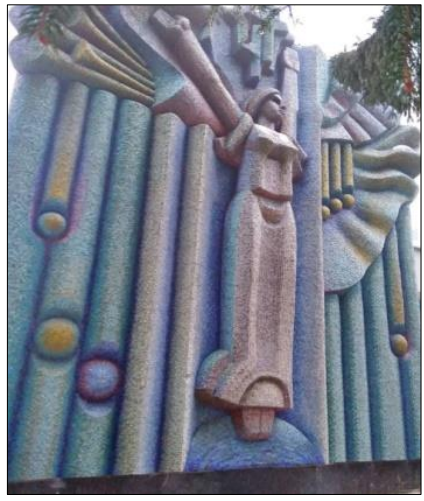

Рис. 14. Пастух Л. «Земля» (800x700, 1982 р., санаторій Військово-повітряних сил, м. Вінниця)

${ }^{21}$ Протоколы заседаний Художественного совета (3 марта 1986 г. - 20 июля 1987 г.) // Державний архів Вінницької області. Ф. 5698. Оп.1. Спр. 289. Арк. 59.

22 Выписки из протокола заседаний Республиканского Художественного совета (11 января - 27 декабря 1978 г.) // Державний архів Вінницької області. Ф. 5698. Оп. 1. Спр. 204. Арк. 35.

23 Документы по работе с молодыми художниками, о монументальнодекоративной живописи (17 января 1979 г. - 13 июня 1979 г.) // Державний архів Вінницької області. Ф. 6025. Спр. 20. Арк.18. 
Високим рівнем художньої майстерності відзначаються мозаїки Леоніда Федоровича Пастуха. Митець народився 25 квітня 1939 р. В с. Карижин Віньковецького району Хмельницької області. У 1959 р. закінчив Косівське училище прикладного мистецтва, у 1968 р. відділення інтер'єру та обладнання Львівського державного інституту прикладного та декоративного мистецтва. Учасник обласних, республіканських виставок. Член Національної Спілки художників України з 1980 р. Найвідомішою монументальною роботою Л. Пастуха $\epsilon$ «Земля» $(800 \times 700)$ для Військово-медичного клінічного центру Центрального регіону. Витримана в зелених та блакитних кольорах, мозаїка передає світ матері-землі, сповнений гармонії та чистоти. Витонченість зображення, орнаментальність композиції, фольклорність зображувальних метафор формують поетичний образ, у якому немає вираженого сюжету, але сам мотив природи, м'які округлі ритми, прозорість кольору надають йому глибокого ліризму (рис. 14).

Слід зазначити, що сьогодні актуальною залишається проблема збереження монументальних творів. На жаль, у Вінницькій області триває тотальне знищення мозаїк, особливо на спорудах приватної форми власності. Зокрема, у 2016 р. було зруйноване геральдичне панно Г. Солдатова на будівлі Вінницької філії Університету сучасних знань (Вінниця, вул. Академіка Янгеля, буд. 4) (рис. 15-16) ${ }^{24}$. На Свропейській площі радянську мозаїку С. Гладкова та I. Синєпольського «Будь гідним епохи ровесником!» закрили банером iз репродукцісю ескізів вінницького художника А. Гайструка (рис. 16-17) ${ }^{25}$.

24 У Вінниці демонтували радянську мозаїку. URL : https://vinbazar.com/ news/nshe/u-vinnitsi-demontuvali-radyansku-mozayiku-foto.

${ }^{25}$ Радянську мозаїку біля Вежі закрили малюнками вінницького художника. URL : https://vinbazar.com/news/suspilstvo/radyansku-mozayiku-bilya-vezhi-zakrilimalyunkami-vinnitskogo-khudozhnika-foto. 


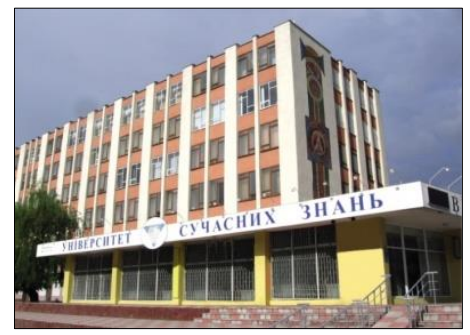

Рис. 15. Солдатов Г.

Геральдична мозаїчна композиція. Колишня будівля Вінницького хімічного заводу імені В. Я. Свердлова

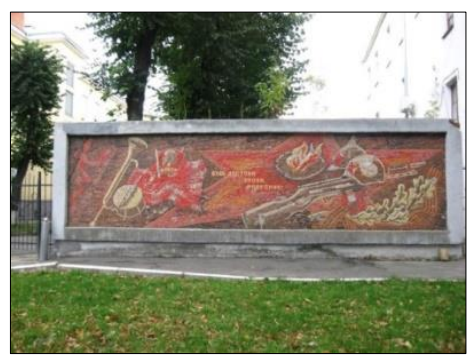

Рис. 17. Гладков С.,

Синєпольський І. Мозаїка «Будь гідним епохи ровесником!» (робоча назва «Пам'ять»).

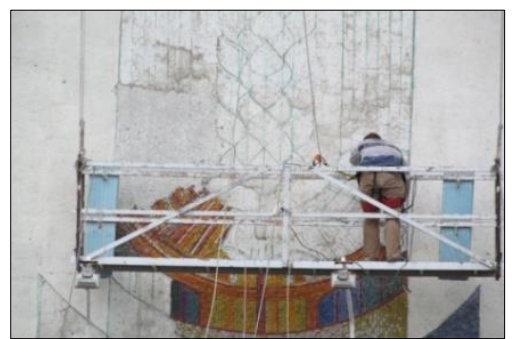

Рис. 16. Демонтаж мозаїки

Г. Солдатова (2016 p.)

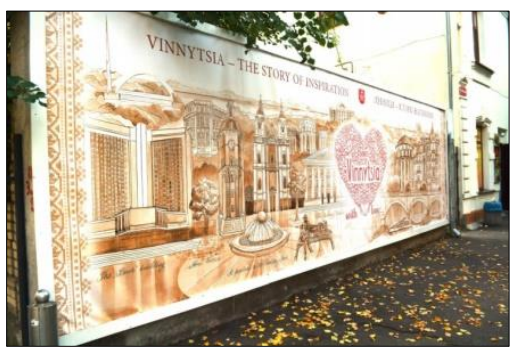

Рис. 18. Гайструк А. «Вінниця - історія натхнення» (2017 p.)

\section{Європейська площа, м. Вінниця}

Науковці, зокрема Н. Піддубна, рекомендують залежно від стану та цінності мозаїк проводити заходи, спрямовані на збереження творів: 1) зберегти без змін та втручань; 2) виконати консервацію (забезпечити збереження автентичності та захистити від руйнувань); 3) здійснити реставрацію (забезпечити збереження автентичності, захистити від руйнувань та доповнити втрати згідно 3 головними принципами реставрації за встановленими нормами ДБН В.3.2-1-2004 «Реставраційні, консерваційні та ремонтні роботи на пам'ятках культурної спадщини»); 4) виконати фахову реконструкцію під авторським наглядом або самим автором); 5) реалізувати депонування (трансфер) - вилучення й перенесення 
мозаїчного панно у спеціально відведене місце для зберігання (музей) та виконання музеєфікації; 6) здійснити консервацію мозаїчного твору під шаром грунту чи тиньку для майбутнього відкриття та дослідження; 7) внести до переліку культурної спадщини для занесення до Державного реєстру нерухомих пам'яток України як об’єкт монументального мистецтва, що $\epsilon$ складовою частиною споруди архітектурної пам'ятки ${ }^{26}$.

\section{2. Технологічні та композиційно-стилістичні складові мозаїк Г. Солдатова}

Монументально-декоративне мистецтво Вінниччини 70-80x pp. $\mathrm{XX}$ ст. засвідчує прагнення художників порушити значущі громадянські теми, здійснити символіко-філософські узагальнення, розширити образну палітру. Серед вінницьких монументалістів, чиї роботи тяжіють до посилення сюжетної лінії, містять атрибути символічного звучання образу людини, прийоми та образи народного мистецтва, $\epsilon$ Геннадій Васильович Солдатов.

Художник народився 22 грудня 1946 p. у Ташкенті $(\text { Узбекистан })^{27}$. У 1966 р. закінчив Ташкентське республіканське художнє училище ім. П. Бенькова (педагог з фаху - Б. Томкін) ${ }^{28}$. Далі вступає до Харківського державного художньо-промислового інституту на факультет «Інтер'єр та обладнання» (педагоги Б. Косарев, С. Бесєдін, С. Солодовник). 31992 р. Г. Солдатов стає членом Національної спілки художників України. На сьогодні його твори зберігаються у Вінницькому краєзнавчому та художньому музеях, Кременчуцькому краєзнавчому музеї, приватних колекціях України, Росії, Італії, США та багатьох інших країн.

Серед найбільш відомих робіт Г. Солдатова $є$ мозаїки «Дари осені» (виконавці Г. Солдатов, В. Одринський, смальта, 1200x800, 1982 р., м. Бар,) (рис. 19) ${ }^{29}$; «Молодість» для санаторію Військово-

${ }^{26}$ Піддубна Н.Г. Композиційні принципи застосування мозаїчних творів в архітектурі Львова кінця XIX - початку XXI століття : дисертація на здобуття наукового ступеня кандидата архітектури : 18.00 .01 - теорія архітектури, реставрація пам'яток архітектури. Міністерство освіти i науки України, Національний університет «Львівська політехніка». Львів, 2018. С. 194-196.

${ }^{27}$ Вінниччина історична в образотворчому мистецтві / Укладач Л. Гринюк. Вінниця : Вінницька обласна організація Національної спілки художників України, 2011. $172 \mathrm{c}$.

${ }^{28}$ Солдатов Г. Живопис. Альбом. Вінниця. 2013. 35 с.

29 Выписки из протокола заседаний Республиканского Художественного совета (20 января - 15 декабря 1982 г.) // Державний архів Вінницької області. Ф. 5698. Оп. 1. Спр. 248. Арк. 18. 
повітряних сил (800х800, 1983 р.) (рис. 20); «Роза вітрів» для туристичного клубу «Меркурій» (500х600, 1986 р.) (рис. 21). Над останньою композицією майстер почав працювати ще в $1982 \mathrm{p.}^{30}$. Найбільш знаним у його творчості є панно «Дари осені» (робоча назва «Родючість»). 3 одного боку, це поетичний образ рідної землі. Через ліричну метафору - буйне квітування трав - автор оспівує радість земного буття, творчої праці. Це почуття виражене проникливо й емоційно через золотаву гаму, музичну ритміку ліній, врівноваженість композиції. 3 іншого боку, провідне місце в роботі посідають образи сучасників - героїв радянського часу, людей праці, сільських трудівників.

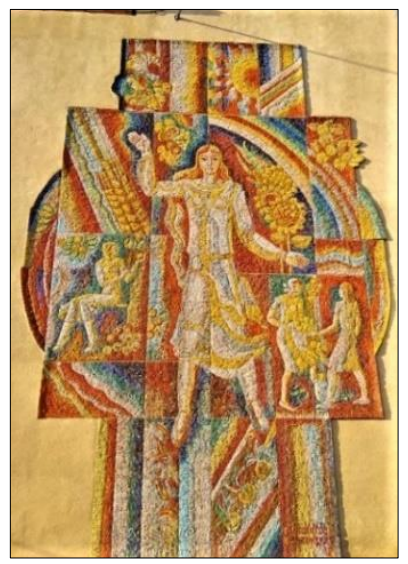

Рис. 19. Солдатов Г., Одринський В. Мозаїка «Дари осені» (1200x800, 1982 р., Барський консервний завод, м. Бар)

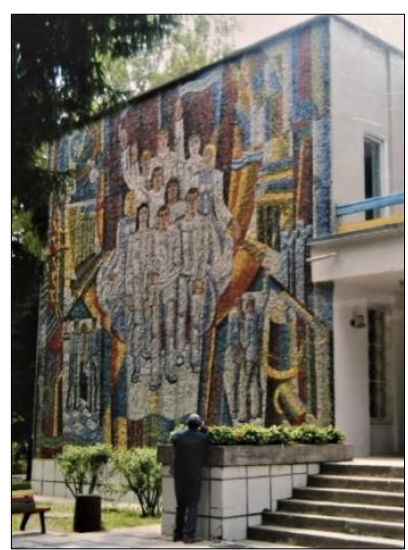

Рис. 20. Солдатов Г. Мозаїка «Молодість» $(800 \times 800$, санаторій

Військово-повітряних сил, м. Вінниця)

Одним із улюблених напрямків роботи Г. Солдатова є оформлення інтер'єрів та екстер'єрів наукових та навчальних установ. Ці твори складають групу, наділену рисами самостійності в системі жанрів монументального мистецтва, саме тут можна спостерігати найбільшу кількість авторських пошуків та яскравих рішень. Майстер зробив безліч ескізів мозаїк для навчальних та наукових установ Вінниччини. Це панно «Юність» (1973 p., 400x550) для Чечелівської ЗОШ І-ІІІ ступенів Гайсинського району

${ }^{30}$ Там само. Арк. 18 зв. 
Вінницької області ${ }^{31}$ (пізніше до реалізації проєкту долучився виконавець С. Кочерган); ескіз монументально-декоративної композиції для фасаду Бабчинецької ЗОШ) ${ }^{32}$. Також митець брав участь у створенні мозаїк для Немирівського коледжу будівництва, економіки та дизайну ВНАУ (рис. 22). Від 1981 р. майстер монументального живопису активно працював з В. Одринським над реалізацією проєкту «Щасливе дитинство» для дошкільного навчального закладу «Веселка» ${ }^{33}$. Назва проєкту засвідчує намір авторів ввести людину в розмаїтий і захопливий сучасний світ).

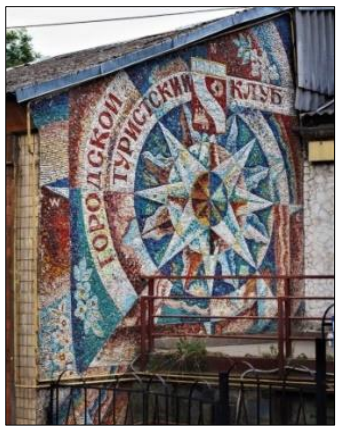

Рис. 21. Солдатов Г. Мозаїка «Роза вітрів» (500x600, 1986 р., туристичний клуб «Меркурій», м. Вінниця)

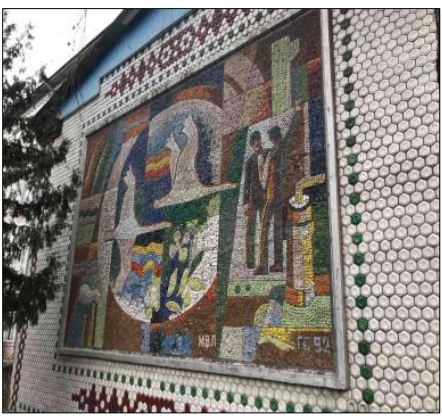

Рис. 22. Солдатов Г.

Мозаїка«Будівельники» (800x800, 1992 р, Немирівський коледж будівництва, м. Немирів)

Мозаїка Г. Солдатова «Будівельники» для Немирівського коледжу будівництва, економіки та дизайну ВНАУ (1992р.) підкорює вільним, неосяжним рухом. Автору вдалося уникнути доволі розповсюдженого в радянський період захоплення «індустріальними» формами, у його творі провідну роль відіграють люди. I в цьому значною мірою сприяло використання давньоруської символіки в поєднанні із сучасною темою.

31 Выписки из протоколов заседений Республиканского художественного совета (24 января 1974 г. - 18 декабря 1974 г.) Державний архів Вінницької області. Ф. 5698. Оп. 1. Спр. 141.Арк.18.

32 Там само.

33 Протоколы заседаний Художественного совета (20 июня 1981-10 октября 1982 г.) // Державний архів Вінницької області. Ф. 5698. Оп.1. Спр. 239. Арк 13 зв. 
Таким чином, Геннадій Солдатов не лише відтворює давні традиції, але й активно популяризує мозаїчне мистецтво на теренах Вінниччини. Оздоблення ним громадських закладів стало символом творчого підходу до вирішення мистецьких завдань. Останнім часом Г. Солдатов активно працює в жанрі портрета.

\section{ВИСНОВКИ}

У радянський період мозаїка набула ідеологічного вираження й агітації. Цей вид монументального декору лише частково компонувався в первісному синтезі з новобудовами - здебільшого митці адаптували композиційні тематичні панно або декор на типові фасади чи площини, надаючи їм естетичного звучання 3 ідейноагітаційним присмаком. Однак на тлі певних суспільноідеологічних програм, закладених у мозаїках цього періоду, особливе місце посідає група вінницьких митців, які зуміли в «політкоректній» формі втілити та підтримати неформальну стилістику, актуальну до сьогодні. У проєктуванні та створенні цих декоративних панно бере участь плеяда провідних вінницьких митців, серед яких Г. Солдатов, В. Байбеков, І. Ященко, Л. Гринюк, В. Ямковенко, В. Коваленко, В. Купчишин, С. Кочерган та ін. Дотримуючись канонів, митці творили згідно з власним духовним досвідом й умовами оточення. Сміливу колористичну палітру, плакатні прийоми використовують у мозаїках С. Кочерган іО. Янголь - випускники Київської художньої академії. Декоративна пластика й техніка мозаїки органічно поєднані в монументальних роботах Л. Пастуха. Античні мотиви читаються в мозаїчному фризі М. Михальчука на фасаді будинку культури в с. Дяківці. Чітку композиційну будову, геральдичну манеру застосовують Г. Солдатов, В. Байбеков. В. Абрамов створив мозаїчну ілюстрацію на тему щасливого дитинства. Яскраве й живе панно В. Одринського й П. Гонтара просякнуте очікуванням чуда, карнавальним настроєм.

Серед художників-монументалістів Вінниччини окреме місце посідає Г. Солдатов. Він намагався уникнути ідеологічного забарвлення. У центрі його композицій найчастіше людина і природа. Ця тема у творчості Г. Солдатова отримала нове тлумачення - ставлення до природи в нього переростає у ставлення до світу, до життя, через природу осягаються основи людського 
буття. Також Г. Солдатов завжди намагався, щоб оздоблена мозаїкою типова споруда набувала ширшого соціального масштабу. Його панно відображають прагнення змінити будівлю, підпорядкувати собі архітектуру, посилити іiі можливості творити середовище.

\section{АНОТАЦІЯ}

Наукова робота присвячена дослідженню проблеми генези та розвитку монументального мистецтва на теренах Вінницької області. Розглянуто історію розвитку традиційних методів створення художньої мозаїки й охарактеризовано різноманітні способи застосування смальти та керамічної плитки для створення композицій у закладах громадського та промислового призначення. Визначено основні композиційні принципи застосування мозаїчних творів в оформленні фасадів, інтер'єрів архітектури Вінниччини. Досліджено мозаїки радянської доби, їх ідеологічне та культурне значення. Вивчено діяльність Г. Солдатова, В. Байбекова, С. Кочергана, спрямовану на відродження монументального мистецтва не лише Вінницької області, але й інших регіонів України. Розглянуто проблему знищення мозаїчних панно в сучасному архітектурному просторі Вінниччини.

\section{ЛІТЕРАТУРА}

1. Велігоцька Н.І. Монументально-декоративное искусство в архитектуре Украины. Київ : Будівельник, 1988. 101 с.

2. Вінницька обласна організація Національної спілки художників України. URL : https://nuau1938.wixsite.com /nuau/vinnuau.

3. Вінниччина історична в образотворчому мистецтві / Укладач Л. Гринюк. Вінниця : Вінницька обласна організація Національної спілки художників України, 2011. 172 с.

4. Выписки из протоколов заседаний Республиканского художественного совета (24 января 1974 г. - 18 декабря 1974 г.) Державний архів Вінницької області. Ф. 5698. Оп.1. Спр. 141. 63 арк.

5. Выписки из протокола заседаний Республиканского Художественного совета (11 января - 27 декабря 1978 г.) // Державний архів Вінницької області. Ф. 5698. Оп. 1. Спр. 204. 67 арк. 
6. Выписки из протоколов заседаний Республиканского Художественного Совета (23 января - 24 декабря 1980 г.) // Державний архів Вінницької області. Ф. 5698. Оп. 1. Спр. 224.73 арк.

7. Выписки из протокола заседаний Республиканского Художественного совета (28 января - 9 декабря 1981г.) // Державний архів Вінницької області. Ф. 5698. Оп. 1. Спр. 238. 53 арк.

8. Выписки из протокола заседаний Республиканского Художественного совета (20 января - 15 декабря 1982 г.) // Державний архів Вінницької області. Ф. 5698. Оп. 1. Спр. 248. 41 арк.

9. Документы по работе с молодыми художниками, о монументально-декоративной живописи (17 января 1979 г. 13 июня 1979 г.) // Державний архів Вінницької області. Ф. 6025. Спр. 20. 56 арк.

10.Дробот А.О. Проблема національного стилю у творчості Г. Синиці (на прикладах мозаїчних панно другої половини XX ст.). Вісник Харківської державної академї дизайну і мистеитв: збірка наукових праџь. 2008. Вип. 13. С. 24-34.

11.Жоголь Л.Е. Декоративное искусство в интерьерах общественных зданий. Киев : «Будивельнык», 1978. 104 с.

12.Закон України «Про засудження комуністичного та націоналсоціалістичного (нацистського) тоталітарних режимів в Україні та заборону пропаганди їхньої символіки» від 9 квітня 2015 p. URL : http://zakon4.rada.gov.ua/laws/show/317-19 від 09.04.2015.

13.Книга протоколов заседания комиссии по распределению заказов (17 февраля 1979 г. - 11 марта 1982 г.) // Державний архів Вінницької області. Ф. 5698. Оп.1. Спр. 215. 148 арк.

14.Лобановський Б. Мозаїки і фрески. Київ : Мистецтво, 1966. $134 \mathrm{c}$.

15.Моляр С. Радянська монументалістика: предмет декомунізації чи урбан-айдентика. URL : https://mistosite.org.ua/ru/articles/ radianska-monumentalistyka-predmet-dekomunizatsii-chy-urbanaidentyka.

16. Моляр $€$. «В Маріуполі має бути створений музей монументально-декоративного мистецтва». URL : http://www.korydor.in.ua/ ua/opinions/yevgeniya-molyar-v-mariupoli-maye-buty-stvorenij-muzejmonumentalno-dekorativnogo-mistetstva.html.

17.Монументальні пам'ятки пізнього модернізму Житомира та Житомирської області. URL : http://monumentalart.in.ua. 
18. Монументальне мистецтво у творчості художників Вінниччини / Вінниц. обл. орг. Нац. спілки художників України ; упоряд.: Л. Гринюк. Вінниця : Консоль, 2009. 119 с.

19. Огнєва Л. Перлини монументального мистецтва на Донеччині. Івано-Франківськ : Лілея, 2008. 52 с.

20.Особова справа Вільдана Байбекова // Центральний державний архів-музей літератури і мистецтв України. Ф. 581. Оп. 2. Спр. 706. 46 арк.

21.Піддубна Н.Г. Композиційні принципи застосування мозаїчних творів в архітектурі Львова кінця XIX - початку XXI століття : дисертація на здобуття наукового ступеня кандидата архітектури : 18.00.01 - теорія архітектури, реставрація пам'яток архітектури / Міністерство освіти і науки України, Національний університет «Львівська політехніка». Львів, 2018. 342 с.

22.Протоколы заседаний Художественного совета (3 марта 1986 г. - 20 июля 1987 г.) // Державний архів Вінницької області. Ф. 5698. Оп.1. Спр. 289. 140 арк.

23. Протоколы заседаний Художественного совета (20 июня 1981 - 10 октября 1982 г.) // Державний архів Вінницької області. Ф. 5698. Оп.1. Спр.239. 148 арк.

24. Радянську мозаїку біля Вежі закрили малюнками вінницького художника. URL : https://vinbazar.com/news/suspilstvo/radyanskumozayiku-bilya-vezhi-zakrili-malyunkami-vinnitskogo-khudozhnikafoto.

25. Скляренко Г. Мистецтво i місто. Роль монументальнодекоративного мистецтва у формуванні естетичного середовища соціалістичного міста. Київ : Товариство «Знання» Української РСР, 1987.48 c.

26. Солдатов Г. Живопис. Альбом. Вінниця. 2013. 35 с.

27.У Вінниці демонтували радянську мозаїку. URL : https://vinbazar.com/news/nshe/u-vinnitsi-demontuvali-radyanskumozayiku-foto.

28. NikiforovY. Decommunized: Ukrainian Soviet Mosaics. Edited by Olga Balashova and Lizaveta German. Kyiv : Osnovy Publishing, 2017. 250 p. 


\section{Information about authors:}

Petrov O. O.,

Candidate of Historical Sciences, Associate Professor of the Department of Documentary and Information Activities

State University of Telecommunications

7, Solomianska Street, Kyiv, Ukraine

Petrova I. V.,

Candidate of Historical Sciences, Associate Professor of the Department of World History and Archeology

Vasyl' Stus Donetsk National University 21, 600-th Anniversary Str., Vinnytsia, Ukraine 